\title{
PERANCANGAN SAMPUL BUKU KOMIK NARCISSUS
}

\section{Maria Gabriella Dwiani, Winny Gunarti Widya Wardani, Febrianto Saptodewo}

Program Studi Desain Komunikasi Visual

Fakultas Bahasa dan Seni Universitas Indraprasta PGRI

Jl. Nangka 58 Tanjung Barat, Jakarta Selatan, Indonesia

mariadwiani@gmail.com

\begin{abstract}
Abstrak
Penelitian ini bertujuan untuk merancang sampul buku komik mitologi Yunani Narcissus sebagai media informasi tentang sifat nasistik pada remaja. Metode yang dilakukan adalah penelitian kualitatif deskriptif dengan membuat deskripsi berdasarkan fakta-fakta yang berasal dari studi pustaka, observasi dan wawancara. Pada umumnya, hal yang pertama kali dilihat oleh pembaca adalah sampul dari buku tersebut. Sampul buku dapat menentukan apakah pembaca tertarik atau tidak untuk membaca isinya. Oleh karena itu, perancangan sampul komik Narcissus ini merupakan upaya peneliti dalam menarik minat para remaja untuk membaca komik Narcissus. Buku komik Narcissus ini menceritakan kisah mitologi demi-god Narcissus yang merupakan akar dari istilah narsistik.
\end{abstract}

Kata Kunci: Narcissus, Sampul, Komik, Mitologi, Perancangan

\begin{abstract}
This study aims to design the cover of the Greek mythology narcissus comic book as a medium of information about nasistic traits in adolescents. The method used is descriptive qualitative research by making descriptions based on facts derived from literature studies, observations and interviews. In general, the first thing a reader sees is the cover of the book. The book cover can determine whether the reader is interested or not to read the contents. Therefore, the design of the Narcissus comic cover is the researchers' effort to attract teenagers to read Narcissus comics. Narcissus comic book tells the mythological story of sake-God Narcissus which is the root of the narcissistic term.
\end{abstract}

Keywords: Narcissus, Cover, Comic, Mythology, Design

\section{PENDAHULUAN}

Narcissus dalam dunia mitologi Yunani merupakan seorang pemburu yang sangat tampan. Dia merupakan putra dari dewa sungai Cephissus dan ibunya adalah seorang bidadari air yang cantik bernama Liriope. Saat Narcissus masih berusia sekitar 16 tahun, ia mendapat kutukan dari Dewi Nemesis karena keangkuhannya. Ia dikutuk agar jatuh cinta pada sosok dirinya sendiri yang terpantul di kolam hingga akhir hayatnya (Kline, 2000: 152-161). Peneliti memilih objek tokoh Mitologi Yunani Narcissus, karena istilah narsisme berakar dari kisah mitologi tersebut.

Narsisme adalah perasaan cinta terhadap diri sendiri yang berlebihan. Orang yang mengalami gejala ini disebut narsisis (narcissist). Istilah ini pertama kali digunakan dalam psikologi oleh Sigmund Freud dengan mengambil dari tokoh dalam mitos Yunani, Narkissos (versi bahasa Latin: Narcissus), yang dikutuk sehingga ia mencintai bayangannya sendiri di kolam (http://psikologid.com/narsisme/, diakses pada 25 Oktober 2018). 
Tokoh mitologi Narcissus ini menarik untuk diangkat karena mencerminkan perilaku narsis pada remaja saat ini. Oleh karena itu, peneliti merancang sampul buku komik Narcissus ini sebagai upaya untuk menarik minat remaja untuk membacanya.

\section{METODE PENELITIAN}

Metode penelitian merupakan langkah yang dimiliki dan dilakukan oleh peneliti dalam rangka mengumpulkan data serta melakukan investigasi pada data yang telah diperoleh. Metode ini bertujuan untuk menemukan pengetahuan baru secara ilmiah yang sebelumnya belum pernah diketahui.

Pada penelitian ini, peneliti menggunakan metode penelitian kualitatif deskriptif. Penelitian dengan membuat deskripsi berdasarkan fakta-fakta yang berasal dari studi pustaka, observasi dan wawancara yang kemudian disusun secara sistematis dan akurat (Nasir, 1988).

Peneliti mengambil tinjauan pustaka utama dari buku berjudul The Metamorphoses yang merupakan sebuah naskah jaman Romawi kuno. Naskah tersebut di tulis oleh seorang penyair Romawi bernama Ovidus pada abad ke 8 SM dan diterjemahkan ke dalam bahasa inggris oleh A.S Kline pada tahun 2000.

Untuk observasi, peneliti mengunjungi toko buku dan perpustakaan, yaitu Gramedia dan perpustakaan Nasional dan perpustakaan UI. Observasi dilakukan untuk mengetahui seberapa besar pangsa pasar buku komik dan gaya visual apa yang digemari oleh remaja saat ini serta adakah media komik tentang mitologi Yunani Narcissus.

\section{HASIL DAN PEMBAHASAN Definisi Komik}

Menurut Scott McCloud dalam buku Understanding Comics, bahwa komik merupakan gambar yang menyampaikan informasi atau menghasilkan respon estetik pada yang melihatnya. Hampir seluruh teks komik tersusun dari hubungan antara gambar atau lambang visual dan kata - kata atau lambang verbal. Gambar dalam komik merupakan gambar-gambar statis yang berurutan yang saling berkaitan satu dengan yang lain yang membentuk sebuah cerita.

Pada sebuah buku komik terdapat cover atau sampul yang terdiri dari tiga bagian, yakni sampul depan, punggung buku dan sampul belakang. Berdasarkan observasi yang peneliti lakukan di beberapa toko buku di Jakarta. Sampul buku pada umumnya berfungsi sebagai pelindung buku agar tidak rusak. Namun selain itu, sampul buku juga memiliki beberapa fungsi lainnya, yaitu yang pertama untuk mengidentifikasikan genre komik tersebut, kedua berfungsi sebagai indikator kredibilitas dan profesionalisme penerbit. Penerbit yang kompeten akan membuat sampul buku dengan desain yang berkualitas dan menarik untuk meningkatkan daya tarik serta nilai jual buku tersebut (www.kompasiana.com, diakses 3 Oktober 2018).

\section{Analisis Khalayak}

Dalam perancangan sampul buku komik Narcissus ini perlu dilakukan analisis khalayak, agar pesan dalam buku komik ini dapat tersampaikan dengan baik sesuai dengan target yang dituju. Oleh karena itu, peneliti perlu melakukan analisis segmentasi, targeting, dan positioning. Sebagai berikut:

1. Segmentasi, Perancangan sampul komik Narcissus ini ditujukan untuk remaja berusia 16 21 tahun yang tinggal di perkotaan, terutama yang aktif di media sosial.

2. Targeting, Perancangan sampul komik Narcissus ini ditujukan untuk para remaja khususnya pria yang aktif di media sosial dan memiliki kegemaran membaca sekaligus mengkoleksi komik.

3. Positioning, Perancangan sampul komik Narcissus ini menggunakan penggabungan gaya visual manga serta menggunakan warna bersaturasi rendah sehingga ilustrasi nyaman untuk dilihat. Hal tersebut diharapkan dapat menjadi daya tarik dari sampul komik Narcissus di mata para pembaca. 


\section{Perancangan}

Penelitian ini bertujuan untuk membuat perancangan sampul buku komik Narcissus. Perancangan sampul komik ini menggunakan teknik menggambar dan pewarnaan digital di perangkat lunak Adobe Photoshop.

Perancangan sampul komik ini, didasari dengan gaya dan simbol-simbol mitologi Yunani. Sampul buku komik ini akan menggunakan bahan soft cover dengan laminating doff, agar memiliki nilai estetika dan berkesan layaknya buku Yunani di jaman modern. Selain itu, ada beberapa elemen dalam perancangan sampul buku komik Narcisus, yaitu:

\section{Tipografi}

Menurut Kusrianto (dalam Rosita, 2014: 63) definisi tipografi adalah sebagai suatu proses seni untuk menyusun bahan publikasi menggunakan huruf cetak hingga merangkainya dalam sebuah komposisi yang tepat untuk memperoleh suatu efek tampilan yang di kehendaki.

Agar pembaca memahami jika karakter Narcissus pada sampul komik merupakan salah satu tokoh mitologi Yunani, maka font atau jenis huruf yang digunakan dalam sampul buku komik Narcissus ini adalah font Ancient Greek.

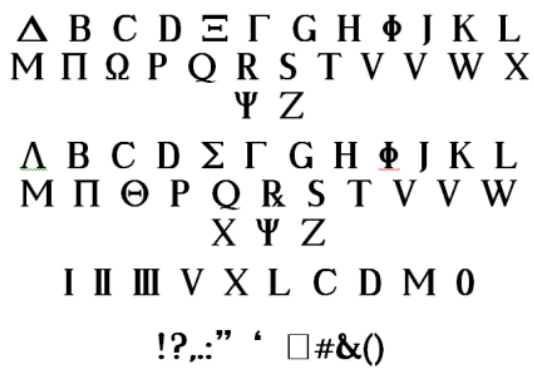

Font tersebut digunakan pada bagian judul buku komik. Alasan peneliti memilih font tersebut, ialah karena buku komik Narcissus ini menceritakan kisah mitologi Yunani.

Sementara itu, untuk bagian sinopsis dan pengarang, peneliti menggunakan font Capitalis TypOasis, karena font ini bersifat tegas dan nyaman untuk dibaca.

\section{A B C D E F G H I J K L$$
\text { MNOPQR ST U V W }
$$$$
X \text { Y Z }
$$

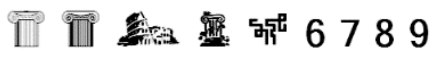$$
\text { !?, .: " \# \#\&() }
$$ \\ Gambar 2 Font Capitalis TypOasis \\ Sumber: Dokumentasi Pribadi}

Warna

Warna yang digunakan dalam perancangan sampul buku komik Narcissus ini di dominasi dengan warna bersaturasi rendah dan benuansa gelap. Hal tersebut dikarenakan buku komik Narcissus ini ditujukan pada pembaca remaja laki-laki.

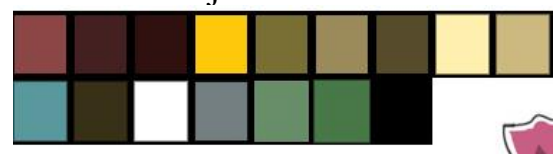

Gambar 3 Aplikasi Warna Pada Sampul Komik Sumber: Dokumentasi Pribadi 


\section{Ilustrasi/Gambar}

Dalam merancang sampul buku komik Narcissus ini, peneliti membuat ilustrasi seorang remaja dan Narcissus yang memiliki wajah dan rupa yang sama namun berbeda pakaian dan jaman. Gaya gambar yang digunakan adalah manga. Peneliti memilih gaya gambar ini karena berdasarkan observasi yang dilakukan di beberapa toko buku, komik yang memakai gaya gambar tersebut yang paling di gemari oleh remaja saat ini.

Pertama - tama, peneliti membuat sketsa sampul komik terlebih dahulu dengan menggunakan perangkat lunak Adobe Photoshop.

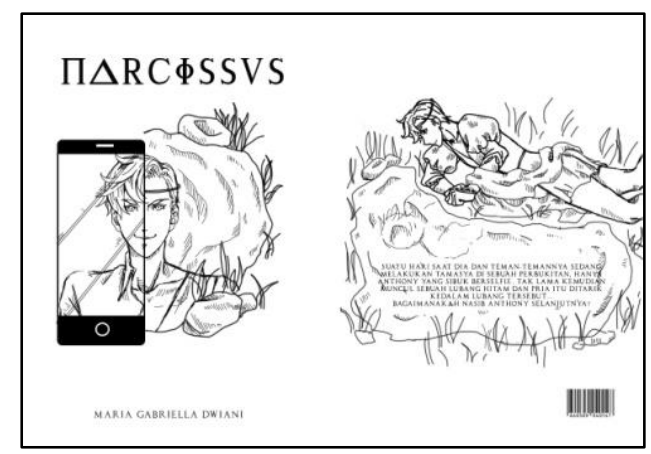

Gambar 4 Sketsa Sampul Buku Komik Narcissus Sumber: Dokumentasi Pribadi

Bagian sampul depan berisi gambar Narcissus yang di bingkai ilustrasi kolam dan sosok seorang remaja yang di bingkai ilustrasi smartphone. Ilustrasi Narcissus dibuat menjadi seperti serupa tapi tak sama. Sampul depan diberi dua warna yaitu, putih dan coklat keemasan untuk memberikan kesan dua dunia yang berbeda. Dalam ilustrasi ini, peneliti bermaksud menggabungkan dunia modern dengan dunia Yunani kuno. Bagian atas sampul ilustrasi Narcissus, terdapat judul "NARCISSUS" yang diberi warna gabungan hitam dan putih untuk memberi penekanan jika sosok Narcissus merupakan dua orang yang berbeda namun memiliki karakter yang serupa.

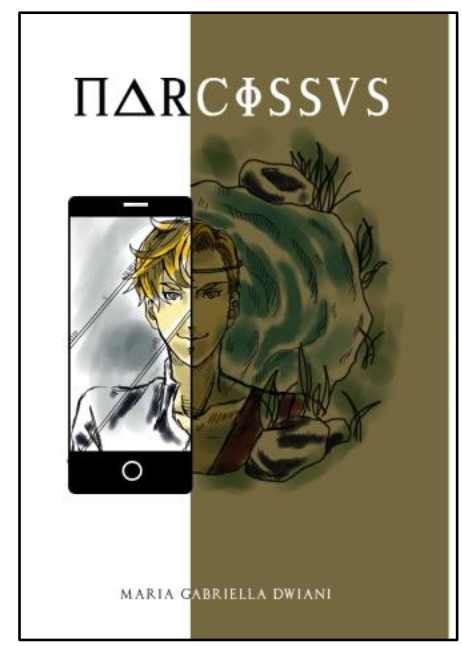

Gambar 5 Desain Sampul Depan Buku Komik Narcissus Sumber: Dokumentasi Pribadi

Sedangkan, pada bagian belakang sampul terdapat ilustrasi berupa Narcissus yang juga sedang terbaring menghadap tanah sambil melihat sosoknya di kolam. Pada bagian ilustrasi kolam, peneliti merancangnya sebagai tempat untuk tulisan sinopsis cerita. 


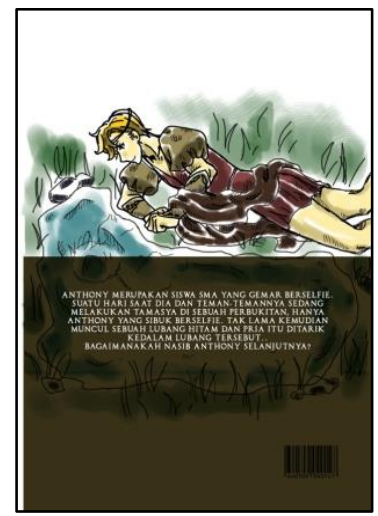

Gambar 6 Desain Sampul Belakang Buku Komik Narcissus Sumber: Dokumentasi Pribadi

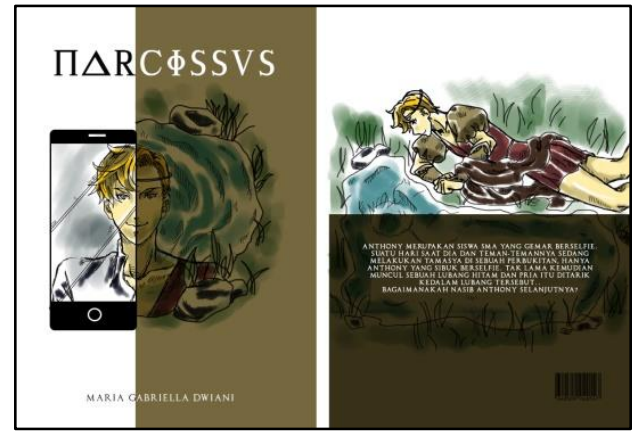

Gambar 7 Desain Sampul Buku Komik Narcissus Sumber: Dokumentasi Pribadi

Mitologi Yunani merupakan kisah tentang berbagai macam makhluk seperti dewa, dewi serta peri dan bidadari. Tiap tokoh memiliki kisah dan pesan moralnya masing - masing mengenai kehidupan. Begitupun dengan tokoh mitologi Narcissus yang di kisahkan terobsesi dengan dirinya sendiri.

Kisah Narcissus ini menarik untuk diangkat karena mencerminkan keadaan remaja saat ini, yakni narsis. Seperti yang terlihat dalam ilustrasi Narcissus yang sedang memandangi sosoknya yang terpantul di kolam. Hal tersebut membuat peneliti tertarik untuk mengangkat kisahnya dalam bentuk buku komik dengan tujuan agar para remaja mendapat pengetahuan tentang pesan moral yang terdapat dalam kisah mitologi Yunani Narcissus ini.

Agar tujuan peneliti tercapai maka langkah pertama yang harus dilakukan adalah merancang sampul buku komik semenarik mungkin dengan menggunakan gaya manga yang saat ini merupakan gaya visual terpopuler dikalangan remaja. Hal tersebut dikarenakan yang pertama kali dilihat oleh pembaca adalah sampul buku tersebut. Sampul buku merupakan penentu apakah pembaca ingin membacanya lebih lanjut atau tidak.

Dalam perancangan sampul buku komik ini, peneliti menggunakan dominasi warna bersaturasi rendah. Warna emas dan coklat merupakan warna yang mendominasi sampul buku komik ini agar memberikan kesan Yunani kuno dan klasik.

\section{SIMPULAN}

Penelitian ini bertujuan untuk merancang cover atau sampul buku komik Narcissus yang ditargetkan untuk pembaca remaja laki-laki. Pada umumnya, hal yang pertama kali dilihat oleh pembaca adalah sampul dari buku tersebut. Sampul buku dapat menentukan apakah pembaca tertarik atau tidak untuk membaca isinya. Oleh karena itu, perancangan sampul komik Narcissus ini merupakan upaya peneliti dalam menarik minat para remaja untuk membaca komik Narcissus. 
Buku komik Narcissus ini menceritakan kisah mitologi demi-god Narcissus yang merupakan akar dari istilah narsistik.

\section{DAFTAR PUSTAKA}

Dwiantoro, E. (2016). Meninjau Desain Cover Buku Komik Terjemahan Karya Tite Kubo Berjudul Bleach Volume 37 Beauty Is So Solitary. Retrieved from https://www.kompasiana.com/edidwian/574e23e1d59273af0dc17cdc/meninjau-desaincover-buku-komik-terjemahan-karya-tite-kubo-berjudul-bleach-volume-37-beauty-isso-solitary.

McCloud, S. (2002). Understanding Comics. Amerika Serikat: HarperPerennial.

Naso, O. (n.d./Tanpa Tahun). Metamorphoses (A.S Kline., Penerjemah). Retrieved from http://tikaboo.com/library/Ovid-Metamorphosis.pdf

Nazir, M. (1988). Metode Penelitian. Jakarta: Ghalia Indonesia.

Rosita, D. Q. (2016). Perancangan tipografi asimilasi aksara latin karakteristik ondel-ondel sebagai solusi kreatif melestarikan budaya betawi. Jurnal Desain, 2(02), 61-68. 